\title{
The Relationship Between of Cash Flows (Financing, Investment and Operating) and Stock Prices, Size of the Firms
}

\author{
Tamer Bahjat Sabri ${ }^{1}$, Khalid Mohammad Hasan Sweis ${ }^{1}$, Issam Naim Mahammad Ayyash ${ }^{1}$, Yasmeen Faheem Asaad \\ Qalalwi $^{1} \&$ Israa Sami Abbas Abdullah ${ }^{1}$ \\ ${ }^{1}$ Department of Computerized Financing and Banking, The College of Business and Economics, Palestine Technical \\ University, Kadoorie, Tulkarm, Palestine
}

Correspondence: Dr. Tamer Bahjat Sabri, Associate Professor, Department of Computerized Financing and Banking, The College of Business and Economics, Palestine Technical University, Kadoorie, Tulkarm, Palestine. E-mail: T.sabri@ptuk.edu.ps

Received: April 18, 2020

Accepted: July 10, 2020

Online Published: October 4, 2020

doi:10.5430/ijfr.v11n5p424

URL: https://doi.org/10.5430/ijfr.v11n5p424

\begin{abstract}
This study sought to test the relationship between cash flows from operating activities, investment activities and financial activities and on one hand and stock returns and the volume of assets on the companies listed in Palestine Stock Exchange on the other hand. The study incorporated 24 companies in 2018 and the required data were obtained through the financial statements. To test the hypotheses of the study, the Mann-Whitny U Test was used, a nonparametric test. Also the Kolmogorov-Smirnov was done. The findings demonstrated that the value of the Whitny U Test was (-3.291) Z with a statistical significance at 1\%. Based on this, the null hypothesis was rejected and the alternative one, stating that there is a statistically significant difference between the operating flows of companies with low assets and those companies with high assets, was accepted. However, the other null hypothesis was accepted. The study recommended that companies and investors should take into consideration cash flows when taking an investment decision in Palestine Stock Exchange.
\end{abstract}

Keywords: cash flows, investment activities, financial activities, Palestine Stock Exchange

JEL Classification Codes: G20; G21; G22

\section{Introduction}

International trade has witnessed enormous growth recently as the markets of most countries have seen economic openness. This has been reflected on the economies of these countries in terms of making them more connected, and contributing to an enormous speed in the movement of capital.

Stocks are considered as the most common investment among investors. In the last few years media has helped spread this type of investment in the world, which in turn has resulted in the ease of buying and selling stocks. Consequently, this has made investors prefer to invest in stocks to other kinds of which were dominant formerly, like investing in real estate.

To make profits fulfilling to investors in the field of stocks, this requires studying their movement in a former period, observing this movement currently, and predicting future movement. To this end, a number of techniques known as fundamental and technical analysis of information related to stocks were used. Among the considerations that the investors should take are financial statements, the growth of organization, separation between management and ownership, the existence of many parties having direct or direct relationship to the activities of the firm

According to (Oround, et.al, 2017), cash flow can be defined as the reporting system which describes the performance of the company in terms of cash. This system is based on matching the in and out cash flows as the statement of cash flows is considered as one of the most important financial statements prepared by firms. Despite the fact that they are recent, compared to the other financial statements, these statements have witnessed a significant development. These statements provide information about receipts and cash payments of companies within the same period in which the other financial statements are prepared. Also the statement of cash flow from financing, operating and investment activities show the company's ability to generate future cash flows enough to pay for the commitments and profit distribution. Besides, cash flow statement balances seek to provide to internal users 
represented by management and accountancy as well as external users represented by those investing in stocks who seek to gain information about the be aware of the current and future financial status of the organisation. Being aware of the cash flows entering the company attracts new investors intending to invest in common stocks as this kind of investment has a lot of popularity among investors since they have high returns on the long run compared to the other investment instruments in the stock market. However, these stocks are considered as the riskiest securities because of huge fluctuations in prices.

According to (Sweis, et. Al., 2019), the political situation in Palestine and the growing unrest have a direct impact on the Palestinian economy and there is no doubt the collapse of stock prices, like what happened in Palestine Stock Exchange in 2006 and 2008, made many investors lose their wealth. This necessitated conducting many studies to identify the nature of relationship between cash flows from operating activities, investment activities and financing activities on one hand and the volumes of companies' assets listed in Palestine Stock Exchange and the prices of stocks. Studies indicate that investors are unaware of the stalemates of cash flows when calculating the market value of stocks. Because of this, there is a need to increase investors' awareness of this issue. There is a need to conduct more studies to identify the factors affecting the market value. Our study raises the following questions:

1. Is there a statistically significant difference between cash flows, (operating, investment and financing), of companies with low assets and those flows (operating, investment and financing) of companies with high assets?

2. Is there a statistically significant difference between cash flows, (operating, investment and financing), of companies with low stock price and those flows (operational, investment and finance) of companies with high stocks price?

\section{Study Objectives}

1. Testing the relationship between cash flows from operating, investment and financing activities and the prices of stocks for the companies listen in Palestine Stock Exchange.

2. Identifying the relationship between cash flows from operating, investment and financing activities and the volume of assets of the companies listen in Palestine Stock Exchange.

\section{Literature Review}

(Suwaidn, 2003) aimed to carry out a trade-off between the models of financial ratios and cash flow in terms of predicting companies' bankruptcy. This study reached the following results. First, the model of financial ratios was superior to the model of cash flows in distinguishing between the companies the declared bankruptcy and those which were not stumbling. Second, there were statistically significant differences in all ratios that make up the ratio model for the last two years before bankruptcy.

(Nasir and Abdullah, 2004) sought to draw a comparison between the information provided by accrual basis and the information provided by cash of cash flows to evaluate the performance of Malaysian organizations. This study concluded that the income statement cannot alone supply information related to operating activities, investment activities and financing investments.

The study of (Talebnia, majlesara, Ghanbari\&Samadiyan, 2013) sought to investigate the effect of cash flows on the levels of investment in companies. The sample of this study included 75 listed in Tehran Stock Exchange between 2010 and 2014. This study found that cash flow has a significant impact on the level of investment. Also the tests of sub- hypotheses showed that the former revenues have a moral influence on the level of investment. Whereas, the future revenues have no moral impact. Besides, the operating income, liability and tangible fixed assets have a moral effect on the level of investment.

The study of (Jabbari \& sadeghi\&Askari, 2013) aimed at investigating the efficiency of operating cash flow in terms of predicting and revealing the risks of the collapse of stock prices. It also aimed to identify the role of operating cash flow on the misleading earnings of companies. The sample of the study consisted of 71companies listed in Tehran Stock Exchange between 2006 and 2010. This study found that there is a statistically significant relationship between the operating cash flow, risk of stock price collapse and misguided earnings of companies. There was an inverse relationship between operating cash flow, risk of stock price collapse and misguided earnings. It was found also that there is a noticeable negative relationship between operating cash flow and misguided earnings.

The study of (KHosroFaghaniMakrani and Mohammad Reza Abd, 2014) aimed to examine the effect book value, net earnings and cash flow on the stock prices between 2007 and 2012. This study consisted of 55 organizations listed in Tehran Stock Exchange in 2014. To test the hypotheses of the study, regression analysis was used. This study found that the effect of book value is greater than the effect of net profits and cash flows on stock value. Besides, the effect 
of these variables did not change for a long period.

(AbdulNafea Al Zararee and Abdulrahman Al-Azzawi, 2014) sought to analyse and study the effect of cash flow ratios to equity rights on the market value of the companies under investigation. This study covered the Jordanian pharmaceutical companies between 2004 and 2010. Using the analysis of sectional data, this study found that cash flows to equity rights have a positive relationship as well as a great impact on the market value of the companies under investigation.

The study of (lbrahim Marwan khanji, Ahmad zakariasiam, 2015) sought to analyse the effect of cash flows on the stock price of the Jordanian commercial banks listed in Amman Stock Exchange. After conducting the regression analysis of the variables, the study found that there is a limited impact of cash flows from operating, investment and financing activities on the market value of these banks' shares. As a result, there is a need to pay more attention to cash flows' behavior when doing stock valuation.

(Mohamed Abouelela and Magdy Fouad Osama, 2016) sought to identify the influence of cash flows on the prices of stocks in the banking sector between 2005 and 2014. This study covered a group of companies listed in the Nigeria Stock Market. To test the hypotheses, the researchers employed the regression analysis. It was found that there is a positive relationship between cash flows and the prices of stocks in the Nigerian banking sector as well as investors should pay more attention to the statements of cash flows before starting any investment.

Finally, (Oroud, et.al, 2017) examined the importance of cash flows in stock markets, focusing whether the information about cash flows affects listed companies' stock prices or not. This study found that cash flows have a statistically significant effect on the prices of the listed companies' stocks.

The goal of our study is to examine the relationship between the cash flows from the investment, operating and financing activities and the prices of the companies' stocks listen in Palestine Stock Exchange. It also aimed at identifying the relationship between the cash flows from the investment, operating and financing activities and the volume of assets of those companies. As far as the researchers know, the current study is different from the previous studies because of the methodology employed. This study also assists researchers and investors as it gives a comprehensive vision about the issue under investigation.

\subsection{Scientific Contributions}

The study of (Suwaidn, 2003) aimed to carry out a trade-off between the models of financial ratios and cash flow in terms of predicting companies. While study of (Talebnia, majlesara, Ghanbari\&Samadiyan, 2013) sought to investigate the effect of cash flows on the levels of investment in companies. However (Jabbari \& sadeghi\&Askari, 2013) aimed at investigating the efficiency of operating cash flow in terms of predicting and revealing the risks of the collapse of stock prices.The study of ( KHosroFaghaniMakrani and Mohammad Reza Abd, 2014) aimed to examine the effect book value, net earnings and cash flow on the stock prices.(AbdulNafea Al Zararee and Abdulrahman Al-Azzawi, 2014) sought to analyse and study the effect of cash flow ratios to equity rights on the market value of the companies under investigation

While the research that we do aims to examine the relationship between the cash flows from the investment, operating and financing activities and the prices of the companies' stocks listen in Palestine Stock Exchange. It also aimed at identifying the relationship between the cash flows from the investment, operating and financing activities and the volume of assets of those companies

This means that this study differs in terms of the goals and methodology used. The difference between the averages has been used (t-test), while previous studies have been used regression analysis. Also, the study is the only one that was applied in Palestine according to the researchers 'knowledge.

\section{Data and Methodology}

\subsection{Data}

The study population consists of the companies listed in Palestine Stock Exchange. The number of these companies is 48 according to the ranking on Palestine Stock Exchange site. This study covers 2018. The study sample is stranded and 24 firms were chosen, 50\% of the listed companies. The study was based on the data published in the annual financial reports of these companies as the sample to calculate the study variables. These data were obtained from Palestine Stock Exchange.

The study sample was divided according to the volume of assets of each company. The first category included 12 companies with high assets. The second one included 12 companies with low assets. Besides, the study sample was divided based on the stock price of those companies. The first category included 12 firms with high stock price, 
whereas the second included 12 companies with low stock price.

\subsection{The Following Hypotheses Were Formulated Based on This}

\section{Hypothesis one:}

H01: There is no statistically significant difference between the operating cash flows of companies with low assets and the operating cash flows of the companies with high assets.

\section{Hypothesis two:}

H02: There is no statistically significant difference between the operating flows of the companies with low stock price and the operating flows of the companies with high stock price.

\section{Hypothesis three:}

H03: There is no statistically significant difference between the financing flows of the companies with low assets and the financing flows of the companies with high assets.

\section{Hypothesis four:}

H04: There is no statistically significant difference between the financing cash flows of the companies with low stock price and the financing cash flows of the companies with high stock price.

\section{Hypothesis five:}

H05: There is no statistically significant difference between the investment flows of the companies with low assets and the investment flows of the companies with high assets.

\section{Hypothesis six:}

H06: There is no statistically significant difference between the investment flows of the companies with low stock price and the investment cash of the companies with high stock price.

\section{Statistical Analysis}

This part covers the descriptive statistics, normality test and correlation test. Also it deals with testing the hypotheses that were formulated in their null formula, using Mann-Whitny U- Two Independent Samples, which is a nonparametric test used to test the differences between the arithmetic means. This test is an alternative to the Independent Samples T-test since the data do not follow the normal distribution.

\subsection{Descriptive Statistics}

This is to show the characteristics of the study variables where the arithmetic mean was used to measure central tendency and the lowest and highest values. The standard deviation was used to measure the dispersion of data around their arithmetic mean.

Table 1. Descriptive statistics

\begin{tabular}{|c|c|c|c|c|c|c|c|c|c|}
\hline & \multirow{2}{*}{$\frac{\mathrm{N}}{\text { Statistic }}$} & \multirow{2}{*}{$\begin{array}{l}\text { Minimum } \\
\text { Statistic } \\
\end{array}$} & \multirow{2}{*}{$\begin{array}{l}\text { Maximum } \\
\text { Statistic } \\
\end{array}$} & \multirow{2}{*}{$\begin{array}{c}\text { Mean } \\
\text { Statistic }\end{array}$} & \multirow{2}{*}{$\begin{array}{c}\text { Std. Deviation } \\
\text { Statistic } \\
\end{array}$} & \multicolumn{2}{|c|}{ Skewness } & \multicolumn{2}{|c|}{ Kurtosis } \\
\hline & & & & & & Statistic & Std. Error & Statistic & Std. Error \\
\hline Op & 24 & -115243518.00 & 58795366.00 & 2592560.6250 & 28895988.13245 & -2.725 & .472 & 13.216 & .918 \\
\hline $\mathrm{Fi}$ & 24 & -16300444.00 & 93657323.00 & 4062161.6667 & 20496032.01959 & 3.954 & .472 & 17.320 & .918 \\
\hline Iv & 24 & -44299000.00 & 158680824.00 & 2992170.1250 & 36040599.92967 & 3.696 & .472 & 16.498 & .918 \\
\hline $\operatorname{Pr}$ & 24 & .00 & 14.10 & 1.8388 & 2.96699 & 3.338 & .472 & 13.191 & .918 \\
\hline As & 24 & 5763942.00 & 2204690870.00 & 294341468.8333 & 528891585.60285 & 2.595 & .472 & 7.054 & .918 \\
\hline $\begin{array}{l}\text { Valid N } \\
\text { (listwise) }\end{array}$ & 24 & & & & & & & & \\
\hline
\end{tabular}

Source: researchers' analysis

OP: cash flows, FI: investment flows, IV: investment flows, Pr: stock price, AS: total of assets

Table one shows that the operating flows (op) averaged 2592560, while the standard deviation was 28895988. The 
financing flows ranged between 16300444 and the highest value was 03657323 . By average, it amounted 4062161 . The total of assets (As) ranged between 5763942 and 2204690870 and this indicated a dispersion in the total of assets.

\subsection{Correlations}

This test is used to measure the strength and direction between two variables.

Table 2. Correlations

\begin{tabular}{llrrrrr}
\hline & & Op & \multicolumn{1}{l}{ Fi } & \multicolumn{1}{l}{ iv } & \multicolumn{1}{c}{ pr } & \multicolumn{1}{c}{ As } \\
\hline op & Pearson Correlation & 1 & $-.787^{* *}$ & .353 & -.030 & .088 \\
& Sig. (2-tailed) & & .000 & .091 & .891 & .682 \\
& $\mathrm{~N}$ & 24 & 24 & 24 & 24 & 24 \\
\hline fi & Pearson Correlation & $-.787^{* * *}$ & 1 & .023 & -.045 & $.460^{*}$ \\
& Sig. (2-tailed) & .000 & & .916 & .833 & .024 \\
& $\mathrm{~N}$ & 24 & 24 & 24 & 24 & 24 \\
\hline iv & Pearson Correlation & .353 & .023 & 1 & .051 & $.706^{* *}$ \\
& Sig. (2-tailed) & .091 & .916 & & .813 & .000 \\
& $\mathrm{~N}$ & 24 & 24 & 24 & 24 & 24 \\
\hline pr & Pearson Correlation & -.030 & -.045 & .051 & 1 & -.025 \\
& Sig. (2-tailed) & .891 & .833 & .813 & & .908 \\
& N & 24 & 24 & 24 & 24 & 24 \\
\hline as & Pearson Correlation & .088 & $.460^{*}$ & $.706 *$ & -.025 & 1 \\
& Sig. (2-tailed) & .682 & .024 & .000 & .908 & \\
& $\mathrm{~N}$ & 24 & 24 & 24 & 24 & 24 \\
\hline
\end{tabular}

**. Correlation is significant at the 0.01 level (2-tailed).

*. Correlation is significant at the 0.05 level (2-tailed).

OP: operating flows, FI: financing flows, IV: investment flows, Pr: stock price, As: total of assets

Source: researchers' analysis

Table two shows the results of correlation analysis between the study variables. The correlations between the variables were disperse in terms of strength and direction. It was found also that there is no relationship between the prices of companies' stocks and operating flows, financing flows and investment flows.

\subsection{Normality}

To test normality, Kolmogorov-Smirnov, and Shapiro-Wilk tests were used.

To judge if the variable is normally distributed, we look at the probability value of each test. If the value is greater than 5\%, we accept the null hypothesis, that is, the data is normally distributed. Table three shows that the data do not follow the normal distribution, so we will depend on a nonparametric test to test the study hypotheses.

Table 3. Tests of normality

\begin{tabular}{lcrrrrr}
\hline & \multicolumn{3}{c}{ Kolmogorov-Smirnov $^{\mathrm{a}}$} & \multicolumn{3}{c}{ Shapiro-Wilk } \\
\cline { 2 - 8 } & Statistic & df & \multicolumn{1}{c}{ Sig. } & Statistic & df & Sig. \\
\hline $\mathrm{Op}$ & .388 & 24 & .000 & .562 & 24 & .000 \\
$\mathrm{Fi}$ & .405 & 24 & .000 & .475 & 24 & .000 \\
\hline $\mathrm{Iv}$ & .402 & 24 & .000 & .516 & 24 & .000 \\
\hline $\mathrm{Pr}$ & .268 & 24 & .000 & .605 & 24 & .000 \\
\hline As & .324 & 24 & .000 & .594 & 24 & .000 \\
\hline
\end{tabular}

a. Lilliefors Significance Correction

Source: researchers' analysis 


\section{Study hypotheses}

\section{Hypothesis one:}

H01: There is statistically significant difference between the operating flows of the companies with low assets and the operating flows of the companies with high assets. To test the first hypothesis, Mann-Whitny $\mathrm{U}$, a nonparametric test, was used. Also, Kolmogorov-Smirnov was administered. The findings showed that the data do not follow normal distribution.

Table four demonstrates the statistic description of these hypotheses data, where the number of companies was 24 and the highest operating flows were 58795366.

Table 4. Descriptive statistics

\begin{tabular}{lrrrrr}
\hline & $\mathrm{N}$ & \multicolumn{1}{c}{ Mean } & Std. Deviation & \multicolumn{1}{c}{ Minimum } & \multicolumn{1}{c}{ Maximum } \\
\hline Opas & 24 & 2592560.6250 & 28895988.13245 & -115243518.00 & 58795366.00 \\
VAR00002 & 24 & 1.5000 & .51075 & 1.00 & 2.00 \\
\hline
\end{tabular}

Source: researchers' analysis

Table five indicates that the value of Mann-Whitny $U$ is (-3.291) with a statistical significance at Z. based on this, the null hypothesis was rejected, and the alternative hypothesis, which states that there is a statistically significant difference between the operating flows of the companies with low assets and the operating flows of the companies with high assets, was accepted.

Table 5. Test statistics

\begin{tabular}{lr}
\hline & \multicolumn{1}{c}{ Opas } \\
\hline Mann-Whitney U & 15.000 \\
Wilcoxon W & 93.000 \\
$\mathrm{Z}$ & -3.291 \\
\hline Asymp. Sig. (2-tailed) & .001 \\
Exact Sig. [2*(1-tailed Sig.)] & $.000^{\mathrm{b}}$ \\
\hline
\end{tabular}

a. Grouping Variable: VAR00002

b. Not corrected for ties.

Source: researchers' analysis

\section{Hypothesis two:}

H02: There is no statistically significant difference between the operating flows of the companies with low stock price and the operating flows of the companies with high stock price.

Table six shows the statistical description of this hypothesis data. The number of companies was 24 and the highest operating flow was 58795366 according to stock price.

Table 6. Descriptive statistics

\begin{tabular}{|c|c|c|c|c|c|}
\hline & $\mathrm{N}$ & Mean & Std. Deviation & Minimum & Maximum \\
\hline Oppr & 24 & 2592560.6250 & 28895988.13245 & -115243518.00 & 58795366.00 \\
\hline VAR00002 & 24 & 1.5000 & .51075 & 1.00 & 2.00 \\
\hline
\end{tabular}

Source: researchers' analysis

Table seven shows the results of Mann-Whitny $U$ where the value of $Z$ was (-462), and this value was not statistically significant at $1 \%$. Based on this, the null hypothesis- there was no statistically significant difference between the operating flows of the companies with low stock price and the operating flows of the companies with high stock price-was accepted. 
Table 7. Test statistics

a. Grouping Variable: VAR00002

\begin{tabular}{lr}
\hline & \multicolumn{1}{c}{ Oppr } \\
\hline Mann-Whitney U & 64.000 \\
Wilcoxon W & 142.000 \\
$\mathrm{Z}$ & -.462 \\
\hline Asymp. Sig. (2-tailed) & .644 \\
Exact Sig. [2*(1-tailed Sig.)] & $.671^{\mathrm{b}}$ \\
\hline
\end{tabular}

b. Not corrected for ties.

Source: researchers' analysis

\section{Hypothesis three:}

H03: There is statistically significant difference between the financing flows of the companies with low assets and the financing flows of the companies with high assets.

Table eight demonstrates the statistical description of the data of this hypothesis. The number of companies is 24 and the highest financing flow is 93657323.

Table 8. Descriptive statistics

\begin{tabular}{|c|c|c|c|c|c|}
\hline & $\mathrm{N}$ & Mean & Std. Deviation & Minimum & Maximum \\
\hline Fias & 24 & 4062161.6667 & 20496032.01959 & -16300444.00 & 93657323.00 \\
\hline VAR00002 & 24 & 1.5000 & .51075 & 1.00 & 2.00 \\
\hline
\end{tabular}

Source: researchers' analysis

Table nine indicates the results of Mann-Whitny $\mathrm{U}$ where $\mathrm{Z}$ is (-404) and this is not statistically significant at $1 \%$. Based on this, the null hypothesis, stating that there is statistically significant difference between the financing flows of the companies with low assets and the financing flows of those with high assets was accepted.

Table 9. Test statistics

\begin{tabular}{ll}
\hline & Fias \\
\hline Mann-Whitney U & 65.000 \\
Wilcoxon W & 143.000 \\
$\mathrm{Z}$ & -.404 \\
\hline Asymp. Sig. (2-tailed) & .686 \\
Exact Sig. [2*(1-tailed Sig.)] & $.713^{\mathrm{b}}$ \\
\hline
\end{tabular}

a. Grouping Variable: VAR00002

b. Not corrected for ties.

Source: researchers' analysis

\section{Hypothesis four:}

H04: There is no statistically significant difference between the financing flows of the companies with low stock price and the financing flows of those companies with high stock price.

Table ten shows the statistical description of this hypothesis data where the number of companies is 24 and the lowest financing flow is 16300444 according to price.

Table 10. Descriptive statistics

\begin{tabular}{lrrrrr}
\hline & $\mathrm{N}$ & \multicolumn{1}{c}{ Mean } & \multicolumn{1}{c}{ Std. Deviation } & \multicolumn{1}{c}{ Minimum } & \multicolumn{1}{c}{ Maximum } \\
\hline Fipr & 24 & 4062161.6667 & 20496032.01959 & -16300444.00 & 93657323.00 \\
VAR00002 & 24 & 1.5000 & .51075 & 1.00 & 2.00 \\
\hline
\end{tabular}

Source: researchers' analysis 
Table eleven indicates the results of Mann-Whitny $\mathrm{U}$ where $\mathrm{Z}$ is (-462) and this is not statistically significant at $1 \%$. Based on this, the null hypothesis, stating that there is statistically significant difference between the financing flows of the companies with low stock price and the financing flows of those companies with high stock price was accepted.

Table 11. Test statistics

\section{a. Grouping Variable: VAR00002}

\begin{tabular}{lr}
\hline & \multicolumn{1}{c}{ Fipr } \\
\hline Mann-Whitney U & 64.000 \\
Wilcoxon W & 142.000 \\
$\mathrm{Z}$ & -.462 \\
\hline Asymp. Sig. (2-tailed) & .644 \\
Exact Sig. [2*(1-tailed Sig.)] & $.671^{\mathrm{b}}$ \\
\hline
\end{tabular}

b. Not corrected for ties.

Source: researchers' analysis

\section{Hypothesis 5:}

H05: There is no statistically significant difference the investment flows of the companies with low assets and investment flows of the companies with high assets.

Table twelve shows the statistical description of this hypothesis data where the number of companies is 24 and the lowest investment flow is -44299000 according to assets.

Table 12. Descriptive statistics

\begin{tabular}{lrrrrr}
\hline & $\mathrm{N}$ & \multicolumn{1}{c}{ Mean } & \multicolumn{1}{c}{ Std. Deviation } & \multicolumn{1}{l}{ Minimum } & \multicolumn{1}{c}{ Maximum } \\
\hline inas & 24 & 2992170.1250 & 36040599.92967 & -44299000.00 & 158680824.00 \\
VAR00002 & 24 & 1.5000 & .51075 & 1.00 & 2.00 \\
\hline
\end{tabular}

Source: researchers' analysis

Table thirteen indicates the results of Mann-Whitny $\mathrm{U}$ where the value of $\mathrm{Z}$ is (-1.617) and this is not statistically significant at $1 \%$. Based on this, the null hypothesis, stating that there is statistically significant difference between the investment flows of the companies with low assets and the investment flows of those companies with high assets, was accepted.

Table 13. Test statistics ${ }^{\mathrm{a}}$

a. Grouping Variable: VAR00002

\begin{tabular}{lr}
\hline & \multicolumn{1}{c}{ Inas } \\
\hline Mann-Whitney U & 44.000 \\
Wilcoxon W & 122.000 \\
$\mathrm{Z}$ & -1.617 \\
\hline Asymp. Sig. (2-tailed) & .106 \\
Exact Sig. [2*(1-tailed Sig.)] & $.114^{\mathrm{b}}$ \\
\hline
\end{tabular}

b. Not corrected for ties.

Source: researchers' analysis

\section{Hypothesis Sixth:}

H06: There is no statistically significant different between the investments flows of the companies with low stock price and the investment flows of the companies with high stock price. 
Table fourteen shows the statistical description of this hypothesis data where the number of companies is 24 and the highest investment flow is 158680824 according to price.

Table 14. Descriptive statistics

\begin{tabular}{lrrrrr}
\hline & $\mathrm{N}$ & \multicolumn{1}{c}{ Mean } & \multicolumn{1}{l}{ Std. Deviation } & \multicolumn{1}{c}{ Minimum } & \multicolumn{1}{c}{ Maximum } \\
\hline inpr & 24 & 2992170.1250 & 36040599.92967 & -44299000.00 & 158680824.00 \\
VAR00002 & 24 & 1.5000 & .51075 & 1.00 & 2.00 \\
\hline
\end{tabular}

Source: researchers' analysis

Table fifteen indicates the results of Mann-Whitny $\mathrm{U}$ where the value of $\mathrm{Z}$ is (-577) and this is not statistically significant at $1 \%$. Based on this, the null hypothesis, stating that there is statistically significant difference between the investment flows of the companies with low stock price and the investment flows of those companies with high stock price, was accepted.

Table 15. Test statistics

a. Grouping Variable: VAR00002

\begin{tabular}{lr}
\hline & \multicolumn{1}{c}{ Inpr } \\
\hline Mann-Whitney U & 62.000 \\
Wilcoxon W & 140.000 \\
$\mathrm{Z}$ & -.577 \\
\hline Asymp. Sig. (2-tailed) & .564 \\
Exact Sig. [2*(1-tailed Sig.)] & $.590^{\mathrm{b}}$ \\
\hline
\end{tabular}

b. Not corrected for ties.

Source: researchers' analysis

\section{Discussion of Findings Related to the Hypotheses}

Despite the accepted belief about the relationship between cash flow and stock price, there are some disagreements whether cash flow influences the fluctuation of prices stock when comparing them to other factors such as profits. Most of the former studies, focusing on the relationship with stock price, used cash flow by employing regression analysis. What makes our study different is that it was applied to Palestine Stock Exchange, using the method of differences between arithmetic means to test the study hypotheses. To the knowledge of the researchers, this makes this study the first of its kind.

The first hypothesis investigated the differences between the operating flows of the companies with low assets and the operating flows of the companies with high assets. The results showed that there is a statistically significant difference between the operating flows of the companies with low assets and the operating flows of the companies with high assets.

The second hypothesis examined whether there is a statistically significant difference between the operating activities of the companies with low stock price and the operating activities of the companies with high stock price. The findings demonstrated that there is no statistically significant difference. This conflicts with the study of AbdulNafea Al Zararee and Abdulrahman Al-Azzawi, 2014.

As for the third, fourth, fifth and sixth hypotheses, the results indicated that there is no statistically significant difference. This is evident that Palestine Stock Exchange is not responsive to the changes in cash flows in general. These findings are compatible with the study of Ahmad zakariasiam, lbrahim Marwan khanji, 2015 which found that there is a limited impact of cash flows from operating, investment and financing activities on the market value of the Jordanian banks' share. As a result of this, there is a need to pay more attention to the behaviour of cash flow when evaluating stock price.

\section{Recommendations}

Based on the findings, the researchers recommend the following: 
1. Investors and companies should take into consideration cash flows when taking the decision of investing in Palestine Stock Exchange. This is compatible with the previous studies which recommend testing the information content of the elements of detailed cash flow statements and comparing them to the totals like cash flows from operating activities, cash flows from investment activities and cash flows from financing activities.

2. Increasing the firm size and its sales as this has a positive impact on the stock price.

3. The researchers recommend conducting more research into this topic because of its importance in financial management.

\section{Acknowledgement}

The researchers thank Palestine Technical University- kadoorie for its constant moral and financial support for this research as well as scientific research in general.

\section{References}

Abdul Nafea, Al Z., \& Abdulrahman, Al-A. (2014, September). The Impact of Free Cash Flow on Market Value of Firm. Global Review of Account ing and Finance, 5(2), 56-63.

Ibrahim, M. K., \& Ahmad, Z. S. (2015). The Effect of Cash Flow on Share Price of the Jordanian Commercial Banks Listed in Amman Stock Exchange. International Journal of Economics and Finance, 7(5), 109-115.

Jabbari, H., Sadeghi, Z., \& Askari, S. A. (2013). Cash Flow, Earning Opacity and its Impact on Stock Price Crash Risk in Tehran Stock Exchange. International Journal of Academic Research in Accounting, Finance and Management Sciences, 3(4).

KHosro, F. M., \& Mohammad, R. A. (2014). The effects of book value, net earnings and cash flow on stock price. Management Science Letters, 2129-2132.

Nasir, N. M., \& Abdullah, S. N. (2004). Information provided by accrual and cash flow measures in determining firms' performance: Malaysian evidence. Am. J. Applied Sci., 1, 64-70. https://doi.org/10.3844/ajassp.2004.64.70

Oroud, Y., Islam, M., \& Salha, T. (2017). The Effect of Cash Flows on the Share Price on Amman Stock Exchange. American Based Research Journal, 6(7), 22-28.

Osama, M. F., \& Mohamed, A. (2016). Analytical Study for the Information Content of Cash Flows Statement and Accounting Earning on the Stock Market Activity Applied Study on Banking Sector in Egypt. Proceedings of 11th Annual London Business Research Conference, Imperial College, London, UK, 25 - 26 July 2016, pp. $1-28$.

Retrieved from https://web.pex.ps

Suwaidan, M. (2003). The Ratio Model versus the Cash Flow Model, and the Prediction of Bankruptcy: An Empirical Examination (Vol. 19.2B, pp. 89-104). Abhath Al - Yarmouk.

Sweis, K., Sabri, T., Alzaghal, Q., Mssis, S., \& Awartani, M. (2019). The Impact of Feasibility Study on Palestinian Small Investment Projects. International Journal of Business Research, 19(3), 65-84.

Talebnia, G., Majlesara, R., Ghanbari, Y., \& Samadiyan, B. (2013). The effect of cash flow on investment level of Listed Companies in Tehran Stock Exchange. Life Science Journal.

\section{Copyrights}

Copyright for this article is retained by the author(s), with first publication rights granted to the journal.

This is an open-access article distributed under the terms and conditions of the Creative Commons Attribution license (http://creativecommons.org/licenses/by/4.0/). 